\title{
Unsaturated Steroid Hydrocarbons as Indicators of Diagenesis in Immature Monterey Shales
}

\author{
W. Giger* \\ Department of Geology, Stanford University, Stanford, Cal. 94305, U.S.A. \\ C. Schaffner \\ Swiss Federal Institute for Water Resources and Water Pollution Control \\ (EAWAG), $\mathrm{CH}-8600$ Dübendorf, Switzerland
}

Steroidal compounds occurring in geologic samples are considered to be derived from biogenically produced sterols. These molecular fossils are altered to different degrees according to the extent of diagenesis that has taken place. Recent sediments contain steroid alcohols [1], steroid ketones [2], and sometimes $\Delta^{2}$-sterenes [3]. 1 mmature petroleum source rocks contain rearranged $\Delta^{13(17)}$-sterenes [4], and in thermally more mature bituminous rocks and in petroleum steranes are most abundant [5]. While laboratory experiments have demonstrated the pyrolytic formation of $A^{4}$ - and $\Delta^{5}$-sterenes from cholesterol [6], these molecules have been only infrequently observed in geologic materials [7]. We report here the predominance of $\Delta^{4}$ - and $A^{5}$-sterenes together with $\Delta^{4 / 5.22}$-steradienes in thermally immature rocks of the Miocene Monterey Formation of California. We propose that these steroid alkenes can be used to assess the thermal history of sedimentary rocks and provide information in addition to conventional maturity parameters.

Rock samples were collected from surface outcrops of the Monterey Formation along the Santa Barbara coast of southern California. The geology and, in particular, the diagenetic silica phase changes of these highly siliceous rocks have been extensively studied [8]. The abundance of biogenic amorphous opal in the outcrops near Santa Barbara is evidence for little diagenetic changes [8]. The Monterey Formation is

* On leave from the Swiss Federal Institute for Water Resources and Water Pollution Control believed to be an important source rock for California crude oils. This report focuses on rocks from the beach near Naples and from Elwood Beach at Goleta $(35 \mathrm{~km}$ west of Santa Barbara).

Collective organic geochemical data (bitumen, total hydrocarbons) show that these samples are immature petroleum source rocks. Total organic carbon contents range from 2.8 to $8.3 \%$. The samples were preextracted with methylene chloride, ground, and then Soxhlet-extracted with methylene chloride. The subsequent separation scheme has been described elsewhere [9]. The unsaturated hydrocarbons were further separated by column chromatography on silver nitrate/silica. In order to ensure that the unsaturated hydrocarbons obtained were not decomposition products caused by sample work-up, one sample was ultrasonically extracted at room temperature. Total saturates and unsaturates were eluted with pentane from a silica column. No differences were observed between the results of this analysis and the results obtained by Soxhlet-extraction and extended clean-up. Gas chromatography was carried out on glass capillary columns which were deactivated by persilylation and coated with SE-52 [10]. Gas chromatography/mass spectrometry analyses were performed on a FINNIGAN system (Model 1015D) combined with an on-line computer (Model 6000).

We have identified four major series of homologous mono- and diolefinic steroid hydrocarbons (sterenes and steradienes) which differ in unsaturation at the $\mathrm{C}-4$, C-5, and C-22 position. A typical gas chromatogram of the unsaturated hydrocar- bons extracted from immature Monterey Shale is shown on Fig. 1. The structures have been assigned by comparing the mass spectra to literature data $[6,11] . \Delta^{5}$-Cholestene coeluted with a commercially available authentic standard on two different

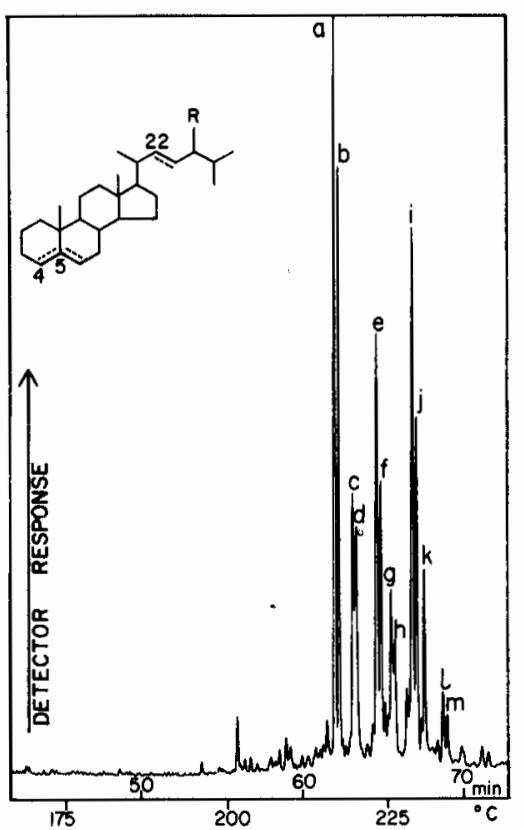

Fig. 1. Gas chromatogram of the unsaturated hydrocarbons extracted from immature Monterey Shale. GC conditions: SE-52, $18 \mathrm{~m} \times$ $0.3 \mathrm{~mm}$ i.d., splitless injection, $2.5^{\circ} \mathrm{C} / \mathrm{min}$ from 70 to $280^{\circ} \mathrm{C}$, flame ionization detection. Peak identifications: (a) $\mathrm{R}=\mathrm{H}, \Delta 4$; (b) $\mathrm{R}=\mathrm{H}$, 45; (c) $\mathrm{R}=\mathrm{CH}_{3}, \Delta 4,22$; (d) $\mathrm{R}=\mathrm{CH}_{3}, \Delta 5,22$; (e) $\mathrm{R}=\mathrm{CH}_{3}, \Delta 4 ;(f) \mathrm{R}=\mathrm{CH}_{3}, \Delta 5 ;(g) \mathrm{R}=$ $\mathrm{C}_{2} \mathrm{H}_{5}, \Delta 4,22 ;$; (h) $\mathrm{R}=\mathrm{C}_{2} \mathrm{H}_{5}, \Delta 5,22 ;(i) \mathrm{R}=$ $\mathrm{C}_{2} \mathrm{H}_{3}, \Delta 4 ;(j) \mathrm{R}=\mathrm{C}_{2} \mathrm{H}_{5}, \Delta 5 ;(k) \Delta 17(21)$-hopene; $(l) \mathrm{R}=\mathrm{C}_{3} \mathrm{H}_{7}, 14 ;(m) \mathrm{R}=\mathrm{C}_{3} \mathrm{H}_{7}, \Delta 5$ 
capillary columns (SE-52, $18 \mathrm{~m}$ and PG$20,40 \mathrm{~m}$ ). No information was obtained to determine the stereochemistry of the side chain $(Z / E$ of the double bond, $R / S$ at C-24). $A^{5}$-Cholestene concentrations in the range from 0.1 to $1.2 \mu \mathrm{g}$ per $\mathrm{g}$ rock were determined. In all samples the steroid olefins predominate over the n-alkanes in the $C_{23}$ to $C_{33}$ range. The relative distribution of the sterenes and steradienes is approximately constant.

The observed predominance of $\Delta^{4}$ and $\Delta^{5}$ steroid alkenes clearly differs from other reports on immature bituminous sedimentary rocks in which rearranged $\Delta^{13(17)}$-sterenes are the most abundant olefinic hydrocarbons [4]. The presence of $\Delta^{4 / 5}$ steroid hydrocarbons with a $\Delta^{22}$-unsaturation can be expected in geologic samples containing $A^{4 / 5}$-sterenes with saturated side chains because both types of steroid alcohols and ketones have been found in Recent sediments $[1,2]$.

Sterols, which could be the precursors of the $\mathrm{C}_{27}, \mathrm{C}_{28}$ and $\mathrm{C}_{29}$ sterenes and steradienes described here, have been isolated from many plants and animals of marine and terrestrial origin. Comparatively little is known on the sterol contents of diatoms despite their importance as major constituents of phytoplankton [12]. Cholesterol, 24-methylcholesterol, 24-methylcholesta5,22-dien-3-ol, 24-ethylcholesterol, and 24ethylcholesta-5,22-dien-3-ol have all been found as principal sterols of marine diatoms $[1,12]$. Since diatoms must have been the major input to the highly siliceous Monterey Formation (up to $75 \%$ silica content [8]), the reported sterene and steradiene compositions of the immature Monterey Shale probably reflect the diatom input, although some terrigenous contribution cannot be excluded. The identification of two $\mathrm{C}_{30}$ sterenes is, to our knowledge, the first conclusive report on a 4-demethy- lated steroid hydrocarbon with thirty carbon atoms in a geologic sample. These molecules were detected as minor constituents in all immature rocks examined. Gorgosterol, the first discovered and best documented marine $\mathrm{C}_{30}$ sterol, cannot be a precursor of our $\mathrm{C}_{30}$ sterenes because of its cyclopropane group in the side chain. The 24-isopropylcholesterol, which was recently isolated from an Australian sponge [13], might be a source.

Our results are circumstantial evidence that the $\Delta^{4 / 5}$-sterenes and $\Delta^{4 / 5,22}$-steradienes are important intermediates in the transformation of steroids in the geologic environment as it has been suggested by Dastillung and Albrecht [3]. Slightly more mature rocks of the Monterey Formation from Gaviota Beach $(30 \mathrm{~km}$ west of $\mathrm{Na}$ ples) do no longer contain these steroid alkenes. The higher maturity of these rocks has been documented by a higher abundance of opal-CT, lower oxygen to carbon atomic ratio of the kerogen [8], higher bitumen content $(57 \pm 23$ compared to $24 \pm$ $7 \mathrm{mg} / \mathrm{g}$ organic carbon), and higher amounts of extractable hydrocarbons $(6.7 \pm 2.5$ compared to $2.5 \pm 0.9 \mathrm{mg} / \mathrm{g}$ organic carbon). In the rocks from Gaviota rearranged $A^{13(17)}$-sterenes (diasterenes) and saturated steranes are dominant instead. The occurrence of $A^{4 / 5}$ unsaturated steroid alkenes with the original steroid skeleton can thus be applied to detect small differences in the thermal history of bituminous sedimentary rocks. The transition from sterenes to diasterenes and steranes occurs during the last part of the diagenetic phase of the formation of petroleum. The stability of the $A^{22}$-steroid alkenes is such that the side chain double bond survives diagenetic processes up to the maturity of our samples.

One author (W.G.) was supported by a fellow. ship of the Swiss National Science Foundation.
We want to thank Dr. C. Isaacs and Prof J. Ingle, Department of Geology, Stanford University, for providing samples and for valuable advice. Glass capillary columns were obtained from Prof. K. Grob and G. Grob, Swiss Federal Institute of Technology. The facilities of the Water Quality Control Research Laboratory, Stanford University, could be used to work up mass spectral data.

\section{Received October 28, 1980}

1. Lee, C., Farrington, J.W., Gagosian, R.B. Geochim. Cosmochim. Acta 43, 35 (1979: Wardroper, A.M.K., Maxwell, J.R., Morris, R.J.: Steroids 32, 203 (1978)

2. Gagosian, R.B., Smith, S.O.: Nature 277 , 287 (1979

3. Dastillung, M., Albrecht, P.: ibid. 269, 678 (1977); Gagosian, R.B., Farrington, J.W.: Geochim. Cosmochim. Acta 42, 1091 (1978)

4. Rubinstein, I., Sieskind, O., Albrecht, P. JCS Perkin I 1975, 1833

5. Seifert, W.K., Moldowan, J.M.: Geochim. Cosmochim. Acta 43, 111 (1979); Ensminger, A., Joly, G., Albrecht, P.: Tetrahedron Lett. I8, 1575 (1978)

6. Rhead, M.M., Eglinton, G., Draffan, G.H.: Chem. Geol. 8, 277 (1971)

7. Anders, D.F., et al., in: Initial Rep. Deep Sea Drilling Project 42, 755 (1976); Simoneit, B.R.T., in : ibid. 43, 643 (1976); Rullkötter, S., von der Dick, H., Welte, D.H., in: ibid. (in press)

8. Isaacs, C.M.: Ph. D. Thesis, Stanford Univ. 1980

9. Giger, W., Schaffner, C.: Anal. Chem. 50 , 243 (1978)

10. Grob, K., Grob, G., Grob, Jr., K.: HRC+ CC 2, 677 (1979)

11. Zaretski, Z.B.: Mass Spectrometry of Steroids. New York: Wiley 1976; Wyllie, S.G., Djerassi, C.: J. Org. Chem. 33, 305 (1968)

12. Goad, L.J., in: Marine Natural Products, Vol. I, p. 75 (ed. Scheuer, P.J.). New York: Academic Press 1978

13. Hofheinz, W., Oesterhelt, G.: Helv. Chim. Acta 62, 1307 (1979) 